\title{
IMPLEMENTASI MODEL PEMBELAJARAN KOOPERATIF TIPE STUDENT TEAMS ACHIEVEMENT DIVISION UNTUK MENINGKATKAN AKTIVITAS DAN HASIL BELAJAR TEKNIK DASAR MENENDANG SEPAKBOLA
}

\author{
I Kadek Suardika ${ }^{1}$, Gede Hendri Setiawan ${ }^{2}$ \\ ${ }^{1,2}$ Jurusan Pendidikan Olahraga, STKIP Agama Hindu Singaraja \\ Singaraja, Indonesia \\ e-mail: deksuguard@gmail.com; hendrimuff@yahoo.com
}

\begin{abstract}
Abstrak
Penelitian ini bertujuan untuk meningkatkan aktivitas dan hasil belajar teknik dasar menendang bola dalam permainan sepakbola pada peserta didik kelas XI IPA I SMA Negeri 1 Sukasada tahun pelajaran 2018/2019. Jenis penelitian ini adalah penelitian tindakan kelas. Pelaksanaan penelitian menggunakan 2 siklus yang masingmasing siklus terdiri dari tahap perencanaan tindakan, pelaksanaan tindakan, observasi/evaluasi, dan refleksi. Data dianalisis menggunakan analisis statistik deskriptif. Hasil penelitian menunjukkan rata-rata aktivitas belajar peserta didik pada siklus I adalah 5,6 berada pada kategori cukup, sedangkan ketuntasan hasil belajar adalah $80 \%$ atau berada pada kategori baik. Pada siklus II rata-rata aktivitas belajar sebesar 7,7 berada pada kategori sangat aktif dan ketuntasan hasil belajar peserta didik mencapai 90\% dalam kategori sangat baik. Disimpulkan bahwa aktivitas dan hasil belajar teknik dasar menendang bola meningkat melalui implementasi model pembelajaran kooperatif tipe Student Teams Achievment Division (STAD) pada peserta didik kelas XI IPA I SMA Negeri 1 Sukasada Tahun Pelajaran 2018/2019
\end{abstract}

Kata-kata kunci : STAD, aktivitas, hasil belajar, menendang bola

\begin{abstract}
Abstrak
The research aimed to improve the activity and learning outcomes of shooting in football in students of class XI IPA I SMA 1 Sukasada in the Academic Year 2018/2019. This research is classroom action research. The form of research action used is the researcher as a teacher. The implementation of the research uses 2 cycles, each of which consists of the stages of action planning, action implementation, observation/evaluation, and reflection. Data were analyzed using descriptive statistical analysis. In the first cycle, the activities is 5,6 in category enough and learning outcomes is $80 \%$ in category good. In cycle II, the activities is 7,7 the category very active and learning outcomes is $90 \%$ in the category very good. It was concluded that the activities and learning outcomes of the shooting football increased through the implementation of the cooperative learning model of the Student Teams Achievement Division (STAD) tin Class XI IPA I SMA 1 Sukasada in the 2018/2019 Academic Year.
\end{abstract}

Keyword : STAD, activity, learning outcomes, shooting. 


\section{PENDAHULUAN}

Guru adalah pendidik profesional dengan tugas mendidik, mengajar, membimbing, mengarahkan, melatih, menilai dan mengevaluasi peserta didik pada pendidikan anak usia dini jalur pendidikan formal, pendidikan dasar, dan pendidikan menengah.

Dalam upaya membelajarkan peserta didik, guru dituntut memiliki multi peran yaitu: sebagai pengajar, pendidik, demonstrator, pengelola kelas, mediator, fasilitator, dan evaluator sehingga mampu menciptakan kondisi pembelajaran yang efektif (Usman, 2005:8). Agar dapat mengajar secara efektif, guru harus meningkatkan kesempatan belajar bagi siswa (kuantitas) dan meningkatkan mutu (kualitas) mengajarnya. Guru dituntut mampu merencanakan program pengajaran yang inovatif sekaligus mampu melaksanakannya dalam bentuk interaksi belajar mengajar. Namun, masalah yang masih sering terjadi dan ditemui dalam dunia pendidikan kita adalah proses pembelajaran masih dilakukan secara klasikal atau kelompok besar, dimana proses pembelajaran ini dilakukan tanpa memperhatikan karakteristik peserta didik. Peranan guru yang sangat dominan dalam proses pembelajaran ini yaitu guru memiliki kekuasaan penuh untuk mengatur dan menentukan proses pembelajaran sehingga menyebabkan siswa kurang mengembangkan kemampuan berpikirnya.

Berdasarkan hasil observasi di kelas XI IPA 1 SMA Negeri 1 Sukasada, ada beberapa permasalahan yang ditemukan berkaitan dengan proses pembelajaran antara lain: kurangnya minat belajar peserta didik khususnya di mata pelajaran penjasorkes membuat proses pembelajaran tidak berjalan dengan efektif dan efesien, peserta didik tidak berani mengemukakan pendapat dan memberikan saran dalam diskusi, peserta didik merasa takut dalam melakukan gerakan-gerakan baru, tidak bersemangat dalam proses pembelajaran, tidak berani memecahkan masalah dalam pembelajaran. Penyampaian materi guru yang kurang membuat variasi model-model pembelajaran dan kurang terstruktur sehingga terasa monoton dan membosankan, serta aktivitas dan hasil belajar peserta didik yang berjumlah 20 peserta didik khususnya dalam pembelajaran pendidikan jasmani, olahraga dan kesehatan (PJOK) pada materi teknik dasar menendang bola dalam permainan sepak bola sangat kurang. Ditinjau dari aktivitas belajar peserta didik masih dalam kategori aktif sebanyak 3 (15\%) orang, kategori cukup aktif sebanyak $12(60 \%)$ orang, kategori kurang aktif sebanyak 5 (25\%) orang, dan tidak ada peserta didik yang berada dalam kategori sangat kurang aktif.

Permasalahan lain juga terdapat pada hasil belajar teknik dasar menendang bola dalam permainan sepakbola dengan menggunakan kaki bagian dalam dan kaki bagian luar dimana peserta didik yang berada dalam kategori sangat baik sebanyak 4 orang (20\%), tidak ada peserta didik yang berada kategori baik, kategori cukup baik sebanyak 9 orang (45\%), kategori kurang baik sebanyak 7 orang (35\%) dan tidak ada peserta didik dalam yang berada dalam kategori sangat kurang baik. Tingkat ketuntasan belajar secara klasikal adalah $65 \%$.

Berdasarkan hal tersebut maka dianggap perlu untuk memperbaiki aktivitas dan hasil belajar peserta didik. Solusi yang diberikan yaitu dengan mengimplementasikan model pembelajaran kooperatif tipe Students Teams Achievement Division (STAD). 
Pada model pembelajaran STAD, guru menyajikan materi secara langsung atau ceramah, kemudian peserta didik dibagi kelompok-kelompok kecil yang beranggotakan 4-5 orang, setiap kelompok harus bervariasi dilihat dari prestasi akademik, jenis kelamin, ras atau etnik. Selanjutnya peserta didik berdiskusi dalam kelompoknya masingmasing dan memperagakan materi yang didiskusikan dengan kelompoknya. Bila semua peserta didik sudah memahami materi tersebut maka guru akan mengadakan permainan akademik atau kelompok. Berdasarkan uraian tersebut, peneliti merasa terdorong untuk melaksanakan penelitian yang berjudul "Implementasi Model Pembelajaran Kooperatif Tipe Student Team Achivement Divicion (STAD) untuk Meningkatkan Aktivitas dan Hasil Belajar Teknik Dasar Menendang Bola dalam Permainan Sepak Bola pada Peserta didik Kelas XI IPA I SMA Negeri 1 Sukasada Tahun Pelajaran 2018/2019".

\section{METODE PENELITIAN}

Jenis penelitian yang digunakan dalam penelitian ini adalah penelitian tindakan kelas (PTK). PTK ini dilaksanakan sebanyak dua siklus dengan masing-masing siklus terdiri dari 2 kali pertemuan. Pertemuan pertama dengan pemberian materi serta observasi aktivitas belajar peserta didik sedangkan pertemuan kedua dengan pemberian materi yang bersifat pengulangan atau pemantapan dan dilakukan observasi aktivitas belajar serta dilakukan evaluasi hasil belajar. Masing-masing siklus terdiri dari empat tahapan, yaitu: (1) Perencanaan tindakan, (2) Pelaksanaan tindakan, (3) Observasi/Evaluasi, dan (4) Refleksi. Agar lebih jelas, dapat di lihat pada gambar 1 di bawah ini:

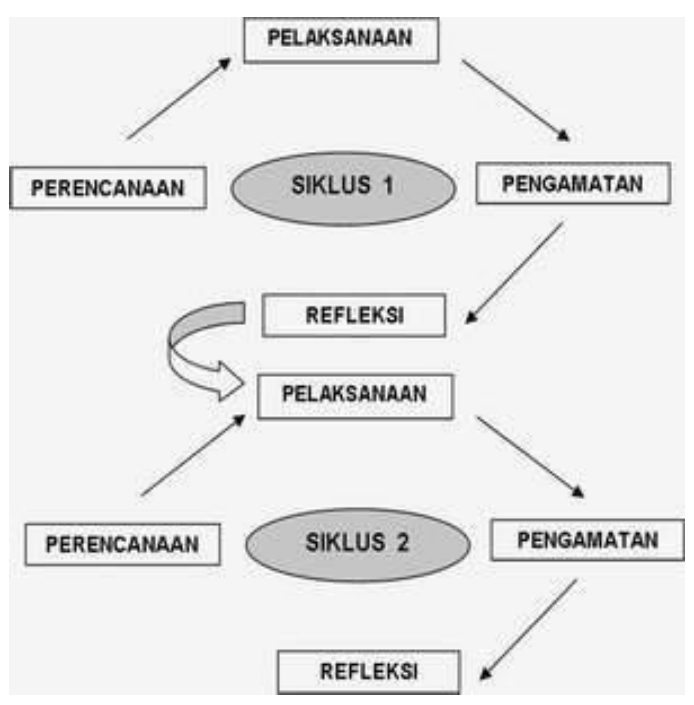

\section{Gambar 1. Rancangan PTK (Kanca, 2010: 139)}

Penelitian ini dilaksanakan pada peserta didik kelas XI-IPA I SMA Negeri 1 Sukasada yang berjumlah 20 orang peserta didik terdiri dari 7 orang putra dan 13 orang putri. Penelitian dilaksanakan di lapangan sepakbola SMA Negeri 1 Sukasada dengan menerapkan model pembelajaran kooperatif tipe STAD dengan materi menendang bola dalam permainan sepakbola.

\section{HASIL DAN PEMBAHASAN \\ Hasil}

\section{a. Siklus I}

Data yang dikumpulkan untuk setiap siklus adalah data aktivitas belajar dan hasil belajar menendang dalam permainan sepak bola. Data aktivitas belajar dikumpulkan setiap pertemuan (2 kali pertemuan). Pada pertemuan I ditemukan nilai rata-rata aktivitas belajar peserta didik yaitu 4,98 (kategori kurang aktif) dan meningkat pada siklus II sebesar 6,28 (kategori cukup aktif). Berdasarkan analisis data aktivitas pada pertemuan I dan II ditemukan hasil aktivitas belajar yaitu sebanyak 19 orang (95\%) berada pada kategori dan 1 orang (5\%) berada pada 
kategori kurang. Nilai rata-rata aktivitas belajar pada siklus I adalah:

$$
\begin{aligned}
\bar{X} & =\frac{\sum X}{N} \\
& =\frac{112,5}{20}=5,6
\end{aligned}
$$

Rata-rata 5,6 berada pada kategori cukup aktif.

Data kedua yang dikumpulkan pada siklus I adalah data hasil belajar menendang bola dalam permainan sepakbola. Berdasarkan analisis data ditemukan bahwa hasil belajar menendang bola secara individu adalah peserta didik dalam kategori sangat baik sebanyak 2 orang (10\%), kategori baik sebanyak 14 orang $(70 \%)$, dan kategori cukup sebanyak 4 orang (20\%). Dilihat dari tingkat ketuntasan belajar, ditemukan bahwa pada siklus I sebanyak 16 orang peserta didik tuntas, dan sisanya 4 orang peserta didik belum tuntas. Tingkat ketuntasan belajar secara klasikal sebagai berikut.

$$
\begin{aligned}
& K K=\frac{\text { Siswa yang Tuntas }}{\text { Siswa Keseluruhan }} \times 100 \% \\
& K K=\frac{16}{20} \times 100 \%=80 \%
\end{aligned}
$$

Keterangan:

KK : Ketuntansan hasil belajar

Berdasarkan data tersebut disimpulkan bahwa tingkat ketuntasan belajar pada siklus I adalah sebesar $80 \%$ atau berada pada kategori baik.

\section{b. Siklus II}

Pada siklus II data aktivitas
belajar dikumpulkan setiap kali
pertemuan. Pada pertemuan I siklus II
ditemukan rata-rata aktivitas belajar
siswa sebesar 6,98 atau berada pada
kategori cukup aktif, dan mengalami
peningkatkan pada pertemuan ke-II
sebesar 8,38 atau berada pada kategori
aktif. Berdasarkan data tersebut

diketahui bahwa nilai rata-rata aktivitas belajar pada siklus II sebagai berikut.

$$
\begin{aligned}
\bar{X} & =\frac{\sum X}{N} \\
& =\frac{153,5}{20}=7,7
\end{aligned}
$$

Nilai rata-rata aktivitas belajar pada siklus II yaitu 7,7 yang berada pada kategori aktif.

Sedangkan, data hasil belajar siklus II menunjukkan bahwa sebanyak 6 orang $(30 \%)$ berada pada kategori sangat baik, sebanyak 12 orang $(60 \%)$ berada pada kategori baik dan 2 orang $(10 \%)$ berada pada kategori cukup baik. Berdasarkan tingkat ketuntasan ditemukan bahwa sebanyak 18 orang siswa tuntas, sedangkan sisanya 2 orang belum tuntas. Tingkat ketuntasan hasil belajar menendang bola dalam permainan sepakbola pada siklus II adalah sebai berikut.

$$
\begin{gathered}
K K=\frac{\text { Siswa yang Tuntas }}{\text { Siswa Keseluruhan }} \times 100 \% \\
\begin{aligned}
K K=\frac{18}{20} \times 100 \% & =90 \% \\
& =90 \%
\end{aligned}
\end{gathered}
$$

Keterangan:

KK : Ketuntansan hasil belajar

\section{Pembahasan}

Berdasarkan data tersebut disimpulkan bahwa tingkat ketuntasan belajar pada siklus I adalah sebesar $90 \%$ atau berada pada kategori sangat baik.

Penelitian tindakan kelas dilaksanakan sebanyak siklus 2 dengan masing-masing siklus terdiri dari 2 kali pertemuan. Setelah memperhatikan data aktivitas belajar pada siklus I, penelitian dilanjutkan pada siklus 2 dengan melihat permasalahan-permasalahan yang ditemukan pada siklus I. Berdasarkan hasil refleksi pada siklus 1 ditemukan lima permasalahan dalam 
pelaksanaan tindakan secara umum yaitu:

1. Peserta didik kurang berani mengajukan pertanyaan tentang materi belajar teknik dasar menendang bola kaki bagian dalam dan kaki bagian luar dalam permainan sepak bola.

2. Peserta didik tidak berani mengemukakan pendapat mengenai materiBelajar teknik dasar menendang bola kaki bagian dalam dan kaki bagian luar dalam permainan sepak bola.

3. Masih ada peserta didik yang tidak mencoba gerakan baru untuk menyempurnakan belajar teknik dasar menendang bola kaki bagian dalam dan kaki bagian luar dalam permainan sepak bola.

4. Masih ada peserta didik yang tidak bisa memecahkan masalah terkait dengan hasil belajar teknik dasar menendang bola kaki bagian dalam dan kaki bagian luar dalam permainan sepak bola.

5. Peserta didik tidak berani menghadapi dan memecahkan masalah terkait dengan Belajar teknik dasar menendang bola kaki bagian dalam dan kaki bagian luar dalam permainan sepak bola.

Berdasarkan hambatan atau kendala yang dihadapi pada siklus 1 maka peneliti memberikan tindakantindakan perbaikan sebagai berikut:

1. Menekankan kepada peserta didik untuk memperhatikan peneliti dalam penyampaian materi dan mengamati peserta didik lain dalam mendemonstrasikan materi teknik dasar menendang bola kaki bagian dalam dan kaki bagian luar dalam permainan sepak bola.

2. Menekankan kepada peserta didik untuk belajar mengajukan pertanyaan yang jelas tentang materi teknik dasar menendang bola kaki bagian dalam dan kaki bagian luar dalam permainan sepak bola.

3. Menekankan kepada peserta didik untuk belajar mengemukakkan pendapat dan saran dalam diskusi kelompok terkait dengan materi teknik dasar menendang bola kaki bagian dalam dan kaki bagian luar dalam permainan sepak bola.

4. Menekankan kepada peserta didik untuk mencoba gerakan baru dalam penyempurnaan materi teknik dasar menendang bola kaki bagian dalam dan kaki bagian luar dalam permainan sepak bola.

5. Menekankan kepada peserta didik untuk belajar cara memecahkan masalah yang dihadapi dalam belajar teknik dasar menendang bola kaki bagian dalam dan kaki bagian luar dalam permainan sepak bola.

6. Menekankan kepada peserta didik untuk berani menghadapi dan memecahkan masalah terkait materi teknik dasar menendang bola kaki bagian dalamdan kaki bagian luar dalam permainan sepak bola.

Sedangkan, dari proses pembelajaran secara umum ditemukan 3 permasalahan yang menghambat hasil belajar yaitu:

1) Peserta didik masih belum mampu melakukan sikap awal dengan benar pada aspek: (a) Letakkan kaki tumpu di samping bola, (b) tekuk kaki tumpu dan rentakan tangan untuk menjaga ke seimbangan, (c) tarik kaki yangakan menendang ke belakang, (d) luruskan kaki yang ditarik kebelakang, dan (e) kepala tidak bergerak dan fokus perhtian pada bola

2) Peserta didik masih belum mampu melakukan sikap pelaksanaan dengan benar pada aspek: (a) luruskan pinggul dah bahu dengan target., (b) tubuh di atas bola, (c) sentakan kaki yang akan menendang sehingga 
lurus, (d) jaga kaki agar tetap kuat, dan (e) tendangan bagian tengah bola dengan kaki bagian dalam

3) Peserta didik masih belum mampu melakukan sikap akhir dengan benar pada aspek: (a) luruskan pinggul dah bahu dengan target, (b) tubuh di atas bola, (c) sentakan kaki yang akan menendang sehingga lurus, dan (d) jaga kaki agar tetap kuat.

Dengan upaya perbaikan permasalahan yang dihadapi pada siklus I, maka pelaksanaan siklus II dapat berlangsung dengan baik. Hal ini dapat dilihat dari adanya peningkatkan aktivitas belajar sebesar 2,1 dari sebelumnya 5,6 (siklus I) menjadi 7,7 pada siklus II. Peningkatkan juga terjadi pada hasil belajar menendang bola sebesar $10 \%$ dari tingkat ketuntasan belajar pada siklus I sebesar $80 \%$ meningkat menjadi $90 \%$ pada siklus II.

Peningkatkan ini tidak terlepas dari implementasi model pembelajaran kooperatif tipe students teams achievement division (STAD). Sebab gagasan utama dari model pembelajaran STAD adalah untuk memotivasi siswa supaya dapat saling mendukung dan membantu sama lain dalam menguasai kemampuan/keterampilan yang diajarkan guru. Jika siswa ingin timnya memperoleh penghargaan tim, maka mereka harus membantu teman satu timnya untuk mempelajari materi. Mereka harus mendukung teman satu tim untuk bisa melakukan yang terbaik, menunjukkan norma bahwa belajar itu penting, beharga, dan menyenangkan. Meski para siswa belajar bersama, mereka tidak boleh saling membantu dalam mengerjakan kuis.

\section{SIMPULAN DAN SARAN \\ Simpulan}

Berdasarkan hasil analisis data dan pembahasan, dapat disimpulkan hal- hal sebagai berikut.

1. Aktivitas belajar teknik dasar menendang bola dalam permainan sepak bola meningkat melalui implementasi model pembelajaran kooperatif tipe STAD pada peserta didik kelas XI-IPA I SMA Negeri 1 Sukasada tahun pelajaran 2018/2019.

2. Hasil belajar teknik dasar menendang bola dalam permainan sepak bola meningkat melalui implementasi model pembelajaran kooperatif tipe STAD pada peserta didik kelas XI-IPA I SMA Negeri 1 Sukasada tahun pelajaran 2018/2019.

\section{Saran}

Berdasarkan simpulan di atas dapat disarankan:

1. Diharapkan kepada peserta didikpeserta didik yang dijadikan subjek penelitian selanjutnya lebih memperhatikan dan memahami pembelajaran yang diberikan, agar dapat menambah wawasan dan pengetahuan khususunya dalam pembelajaran materi teknik dasar menendang bola dalam permainan sepak bola maupun pada pembelajaran yang lain.

2. Disarankan kepada guru PJOK agar menerapkan model pembelajaran kooperatif tipe STAD, karena terbukti dapat meningkatkan aktivitas dan hasil belajar teknik dasar menendang bola dalam permainan sepak bola

3. Bagi sekolah agar dijadikan pedoman dalam pembelajaran pendidikan jasmani, olahraga dan kesehata khususnya pada materi teknik dasar menendang bola (Shooting) dalam permainan sepak bola.

4. Bagi peneliti lain yang akan mengadakan penelitian dapat 
menggunakan model pembelajaran kooperatif tipe STAD.

\section{DAFTAR PUSTAKA}

Departemen Pendidkan Nasional, 2006. Badan Standar Nasional Pendidikan

Dimayanti dan Mudjiono. 2006, Belajar dan Pembelajaran. Jakarta: PT RINEKA CIPTA

Erlangga, 2006. Pendidikan Jasmani olahraga dan kesehatan. Jakarta: Departemen Pendidikan Nasional

Hamalik. 2008. Proses Belajar Mengajar. Jakarta: Bumi Aksara.

Hamalik,Omar. 2004. Proses Belajar Mengajar. Jakarta : Bumi Aksara.

Kanca, I Nyoman. 2006. Metode Penilitian Pengajaran Pendidikan
Jasmani dan Olahraga Singaraja: Universitas Pendidikan Ganesha.

Nurhadi, ddk. 2004. Pembelajaran kontekstual dan Penerapam $K B K$. Malang: Universitas Negeri Malang.

Rusman, 2010. Model-,Model Pembelajaran Mengembangkan Profesionalisme Guru. Jakarta: PT RajaGrafindo

Satyawan, 2012. Permainan Sepak Bola.

Suprianjono, A. 2009. Cooperativ leariing Teori dan Aplikasi. Yogjakarta: Pustaka Belajar

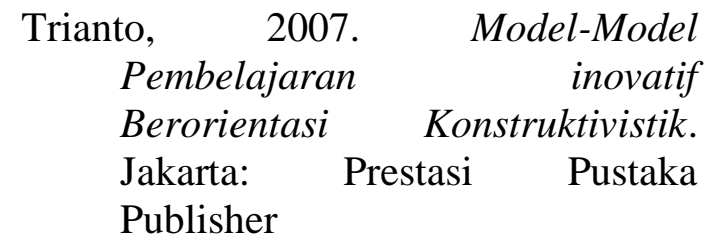

